\title{
Immune derangement occurs in patients with H7N9 avian influenza
}

\author{
Wei $\mathrm{Wu}^{\dagger}$, Yu Shi ${ }^{\dagger}$, Hainv Gao, Weifeng Liang, Jifang Sheng and Lanjuan Li
}

\begin{abstract}
Introduction: Currently, little is known about the immunological characteristics of patients with avian influenza A (H7N9) virus infection.

Methods: The numbers and percentages of peripheral blood immune cells were measured in 27 patients with laboratory-confirmed H7N9 virus infection and 30 healthy controls (HCs). The functional phenotypes of T cells and monocytes, as well as serum cytokine levels, were analyzed by flow cytometry.

Results: There were 19 patients (70.4\%) with acute respiratory distress syndrome, 13 (48.1\%) with secondary respiratory infection, 20 (74\%) with systemic inflammatory response syndrome (SIRS; defined as having at least two concurrent SIRS components), 18 (66.7\%) with lymphocytopenia and 11 (40.7\%) with reduced numbers of monocytes. In comparison with levels in the HCs, the levels of serum interleukin 6 (IL-6), IL-8 and IL-10 and the percentages of CD38+ or Tim-3+ T cells were significantly increased. However, the percentages of human leukocyte antigen-DR + and Tim-3+ monocytes were significantly decreased in patients compared with HCs.
\end{abstract}

Conclusions: Patients with avian H7N9 virus infection display profound SIRS concomitantly with an anti-inflammatory response, which may be associated with the rapid progression of and high mortality associated with this novel viral disease.

\section{Introduction}

Recently in China, an outbreak of influenza occurred that was caused by a novel influenza A (H7N9) viral infection of avian origin. According to published reports, patients with H7N9 virus infection present with rapid, progressive pneumonia commonly leading to the development of acute respiratory distress syndrome (ARDS), respiratory failure and even multiorgan dysfunction syndrome [1]. More importantly, patients with H7N9 virus-mediated influenza have a high mortality rate [2]. Previous studies have revealed the clinical characteristics [1], epidemiology [3-5] and virology [6,7], laboratory diagnosis, and treatment of patients with H7N9 virus infection $[8,9]$. However, little is known about the impact of H7N9 virus infection on the immune system.

\footnotetext{
* Correspondence: lji@@ju.edu.cn

${ }^{\dagger}$ Equal contributors

Collaborative Innovation Center for Diagnosis and Treatment of Infectious Diseases, State Key Laboratory of Diagnostic and Treatment of Infectious Diseases, The First Affiliated Hospital, Zhejiang University School of Medicine, Qingchun Road No 79, Hangzhou 310003, China
}

In this paper, we describe the cytokine profiles and functional phenotypes of immunocompetent cells in $27 \mathrm{pa}-$ tients with H7N9 virus-mediated influenza and 30 healthy controls (HCs). We determined the functional phenotypes of immunocompetent cells and serum cytokine profiles of the participants. We describe the cytokine profiles and functional phenotypes of immunocompetent cells in 27 patients.

\section{Materials and methods \\ Patients}

We recruited 27 patients with $\mathrm{H} 7 \mathrm{~N} 9$ virus-mediated influenza and 30 healthy controls (HCs). The patients with avian influenza were recruited from the Inpatient Service at The First Affiliated Hospital of Zhejiang University School of Medicine between 10 and 22 April 2013. Individual patients with H7N9 were diagnosed on the basis of clinical symptoms and laboratory-confirmed H7N9 virus infection. Patients with ARDS were diagnosed according to standard criteria [10]. Thirty age- and gender-matched HCs were recruited at the Physical Examination Center of

\section{Ciomed Central}


the hospital during the same period. The mean age of the HCs was $57 \pm 12$ years, and $56.7 \%$ of them were male (17 participants). The exclusion criteria were (1) coinfection with hepatitis $\mathrm{B}$ virus (HBV), hepatitis $\mathrm{C}$ virus (HCV) or HIV; (2) the presence of a common autoimmune disease and tumor; and/or (3) a recent history of chemotherapy, radiotherapy or use of immunosuppressants. Written informed consent was obtained from each participant. The experimental protocol was established in accordance with the Declaration of Helsinki and approved by the Ethics Committee of The First Affiliated Hospital of Zhejiang University School of Medicine. The patients' demographic and clinical characteristics are shown in Table 1.

\section{Laboratory examination of H7N9 virus patients}

Sputum samples were collected from individual patients immediately after hospitalization, and the presence of H7N9 virus in the collected sputum samples was determined by real-time RT-PCR as previously described [8]. Briefly, the presence of the $\mathrm{M}, \mathrm{H} 7$ and N9 genes of the H7N9 virus was detected by TaqMan real-time RT-PCR assays (Applied Biosystems, Foster City, CA, USA) using specific primers. The sequences of primers and probes used were as follows: $M$ forward: 5'-GAGTGGCTAAA GACAAGACCAATC-3'), M reverse: 5'-TTGGACAAA GCGTCTACGC-3' and M probe: 6-carboxyfluorescein (6-FAM)-TCACCGTGCCCAGTGAGCGAG-black hole quencher 1 (BHQ1); H7 forward: AGAGTCATTRCARA ATAGAATACAGAT, H7 reverse: CACYGCATGTTTC CATTCTT and H7 probe: 6-FAM-AAACATGATGCCC CGAAGCTAAAC-BHQ1; and N9 forward: GTTCTAT GCTCTCAGCCAAGG, N9 reverse: CTTGACCACCCA ATGCATTC and N9 probe: hexachlorofluorescein-TAA GCTRGCCACTATCATCACCRCC-BHQ1. The sensitivity of these RT-PCR assays was approximately 100 copies/ml RNA.

\section{Flow cytometry}

Venous blood samples were collected from individual patients immediately after hospitalization and from HCs when they visited the hospital. To characterize the frequency of $\mathrm{T}$, natural killer (NK) and B cells, individual blood samples $(0.5 \mathrm{ml})$ were stained with the following antibodies: phycoerythrin (PE) cyanine 5-conjugated (Pcy5) anti-CD3, fluorescein isothiocyanate (FITC)-conjugated anti-CD4, PE-conjugated anti-CD8 (BD Biosciences, San Jose, CA, USA), PE-conjugated anti-CD16/ anti-CD56 or FITC-conjugated anti-CD19 (Beckman Coulter, Brea, CA, USA). Furthermore, to characterize T-cell immunoglobulin mucin 3-positive (Tim-3+) or CD38+ T cells, blood samples were stained with the following antibodies: Pcy5-conjugated anti-CD3, FITC-conjugated anti-CD4, FITC-conjugated anti-CD8, PE-conjugated antiTim-3 (R\&D Systems, Minneapolis, MN, USA) or PE-
Table 1 Demographic, epidemiologic and clinical characteristics of 27 patients with H7N9 virus infection ${ }^{\text {a }}$

\begin{tabular}{|c|c|}
\hline Variables & Values \\
\hline Age (years) & $62 \pm 14$ \\
\hline Male, $n(\%)$ & $16(59.3)$ \\
\hline Smoker, $n(\%)$ & $8(29.6)$ \\
\hline Exposure to live poultry, $n(\%)$ & $16(59.3)$ \\
\hline \multicolumn{2}{|l|}{ Underlying conditions, $n$ (\%) } \\
\hline Any & $15(55.6)$ \\
\hline Hypertension & $13(48.1)$ \\
\hline Coronary heart disease & $2(7.4)$ \\
\hline Diabetes mellitus & $3(11.1)$ \\
\hline Chronic obstructive pulmonary disease & $1(3.7)$ \\
\hline Other & $7(25.9)$ \\
\hline Days between disease onset and admission & $1.0(0.5$ to 19.0$)$ \\
\hline White blood cell count $\left(10^{9} / \mathrm{L}\right)$ & $5.1 \pm 3.0$ \\
\hline Hemoglobin (g/dl) & $123 \pm 24$ \\
\hline Platelet count $\left(10^{9} / \mathrm{L}\right)$ & $132 \pm 46$ \\
\hline Alanine aminotransferase $(\mathrm{U} / \mathrm{L})(n=26)$ & 36 (12 to 262$)$ \\
\hline Creatinine $(\mu \mathrm{mol} / \mathrm{L})$ & 57 (25 to 266$)$ \\
\hline Potassium (mmol/L) & $4.37 \pm 0.48$ \\
\hline Sodium (mmol/L) & $139 \pm 4$ \\
\hline International normalized ratio & $1.08 \pm 0.093$ \\
\hline D-dimer $(\mu \mathrm{g} / \mathrm{L})(n=26)$ & $2,790$ (120 to 42,920$)$ \\
\hline $\mathrm{PaO}_{2}: \mathrm{FiO}_{2}$ ratio & $143.26 \pm 58.38$ \\
\hline
\end{tabular}

Chest radiological abnormalities

$\begin{array}{ll}\text { Involvement of both lungs }(n=26) & 18(69.2) \\ \text { Ground-glass opacities }(n=21) & 2(8.7) \\ \text { Pulmonary consolidation } & 25(92.6) \\ \text { APACHE II score } & 22.26 \pm 7.70 \\ \text { Complications } & \\ \text { Acute respiratory distress syndrome, } n(\%) & 19(70.4) \\ \text { Secondary infection, } n(\%) & 13(48.1) \\ \text { Liver damage, } n(\%)(n=26) & 12(44.4) \\ \text { Shock, } n(\%) & 6(22.2) \\ \text { Acute renal injury, } n(\%) & 1(3.7) \\ \text { Antiviral therapy with oseltamivir, } n(\%) & 27(100) \\ \text { Glucocorticoid therapy, } n(\%) & 10(37.0) \\ \text { Mechanical ventilation, } n \text { (\%) } & 13(48.1) \\ \text { Extracorporeal membrane oxygenation, } n(\%) & 9(33.3)\end{array}$

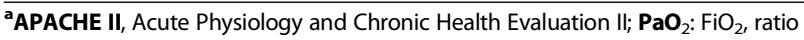
of partial pressure of arterial oxygen to fraction of inspired oxygen. Continuous data were expressed as mean \pm SD or median (range), and categorical data were represented as number (percentage).

conjugated anti-CD38 (Beckman Coulter). In addition, to characterize Tim-3+ and HLA-DR + monocytes, wholeblood samples were stained with antibodies against FITCconjugated anti-CD14 and allophycocyanin-conjugated 
anti-Tim-3 (R\&D Systems) or PE antibodies against major histocompatibility complex class II cell surface receptor encoded by the human leukocyte antigen (anti-HLA-DR) (BD Biosciences). The isotype-matched immunoglobulins were used as controls. The frequency of different types of immunocompetent cells was characterized by flow cytometry, and at least $1 \times 10^{5}$ events were analyzed using an FC500 MPL flow cytometer (Beckman Coulter) or an Accuri C6 cytometer (BD Biosciences).

\section{Measurement of serum cytokines}

Individual serum samples were obtained from patients immediately after hospitalization and from HCs when they visited the hospital. The concentrations of serum interferon $\gamma$ (IFN- $\gamma$ ), tumor necrosis factor $\alpha$ (TNF- $\alpha$ ), TNF- $\beta$, interleukin $1 \beta$ (IL-1 $\beta$ ), IL-2, IL-4, IL-5, IL-6, IL8 , IL-10 and IL-12P70 in individual participants were determined by cytometric bead array (CBA) using a FlowCytomix Simplex Kit (Bender MedSystems/eBioscience, San Diego, CA, USA), according to the manufacturer's instructions, which were described previously [11]. The concentrations of individual serum cytokines were determined using standard curves established with the individual recombinant cytokines provided. The limitation of detection was $1.6 \mathrm{pg} / \mathrm{ml}$ for IFN- $\gamma, 3.2 \mathrm{pg} / \mathrm{ml}$ for TNF- $\alpha$, $2.4 \mathrm{pg} / \mathrm{ml}$ for TNF- $\beta, 4.2 \mathrm{pg} / \mathrm{ml}$ for IL- $1 \beta, 16.4 \mathrm{pg} / \mathrm{ml}$ for IL-2, $20.8 \mathrm{pg} / \mathrm{ml}$ for IL-4, $1.6 \mathrm{pg} / \mathrm{ml}$ for IL-5, $1.2 \mathrm{pg} / \mathrm{ml}$ for IL-6, $0.5 \mathrm{pg} / \mathrm{ml}$ for IL-8, $1.9 \mathrm{pg} / \mathrm{ml}$ for IL-10 and $1.5 \mathrm{pg} / \mathrm{ml}$ for IL-12P70.

\section{Statistical analysis}

Continuous data are expressed as mean \pm SD or median (range), and categorical data are given as percentages. Comparison of the data between the two groups was analyzed by Student's $t$-test, Mann-Whitney $U$ nonparametric test and $\chi^{2}$ test using SPSS 16.0 for Windows software (SPSS, Chicago, IL, USA). A twosided $P$-value less than 0.05 was considered statistically significant.

\section{Results}

Demographic, epidemiological and clinical characteristics of the study population

A total of 27 patients with confirmed avian-origin influenza A (H7N9) virus infection and $30 \mathrm{HCs}$ were recruited for participation in this study. Their demographic and clinical characteristics are presented in Table 1. There were no significant differences between the patients and $\mathrm{HCs}$ in our sample population with regard to age or gender. After hospital admission, sputum samples were collected from individual patients and subjected to characterization of H7N9 virus genes. The sputum samples from all patients were positive for the M, H7 and $\mathrm{N} 9$ genes as determined by RT-PCR, confirming that all the patients had H7N9 avian-origin influenza virus infection. Of the 27 patients, 8 (29.6\%) were smokers and 16 (59.3\%) had a definitive history of poultry exposure. Furthermore, $55.6 \%$ of the patients had preexisting chronic diseases, such as hypertension.

Chest radiographs showed that all patients displayed significant changes, and $92.6 \%$ of them had bilateral consolidation in the lungs. Most patients were in critical condition, with an average Acute Physiology and Chronic Health Evaluation II score of $22.26 \pm 7.70,70.4 \%$ developed ARDS and $48.1 \%$ had secondary infections in the respiratory tract. In addition, many patients developed severe complications, including liver damage (44.4\%), renal injury (3.7\%) and shock (22.2\%). All patients were given oral antiviral therapy with oseltamivir, and $10(37.0 \%)$ received glucocorticoid treatment. Approximately one-half of the patients (13 (48.1\%) of 27) required mechanical ventilation, and 9 of them received extracorporeal membrane oxygenation.

\section{Patients with H7N9 avian influenza developed systemic inflammatory response syndrome at admission}

Many patients with clinical presentation of H7N9 avian influenza developed systemic inflammatory response syndrome (SIRS)-related clinical symptoms and signs, such as abnormalities in body temperature, heart rate, respiratory rate and leukocyte count [12], suggesting that a hyperactivated inflammatory response may play a pivotal role in disease progression. We found that $70 \%$ patients had at least two concurrent SIRS components. In addition, 92.6\% of patients had increased levels of serum C-reactive protein, 33.3\% had elevated levels of serum procalcitonin and $77.8 \%$ had abnormally high erythrocyte sedimentation rates (Table 2).

\section{Table 2 Systemic inflammatory response syndrome components and clinical inflammatory markers in 27 patients with $\mathrm{H7N} 9$ virus infection ${ }^{\mathrm{a}}$}

\begin{tabular}{ll}
\hline Variables & Frequency \\
\hline Body temperature $<36^{\circ} \mathrm{C}$ or $>38^{\circ} \mathrm{C}, n(\%)$ & $24(88.9)$ \\
Heart rate $>90$ beats/min, $n(\%)$ & $7(25.9)$ \\
Respiratory rate $>20$ breaths/min or & $13(48.1)$ \\
$\mathrm{PaCO}_{2}<32 \mathrm{mmHg}, n(\%)$ & \\
WBC count $<4 \times 10^{9} / \mathrm{L}$ or $>12 \times 10^{9} / \mathrm{L}, n(\%)$ & $13(48.1)$ \\
Maximum two concurrent components, $n(\%)$ & $11(40.7)$ \\
Maximum three concurrent components, $n(\%)$ & $7(25.9)$ \\
Maximum four concurrent components, $n(\%)$ & $2(7.4)$ \\
C-reactive protein $>10 \mathrm{mg} / \mathrm{dl}, n(\%)$ & $25(92.6)$ \\
Erythrocyte sedimentation rate $>20 \mathrm{~mm} / \mathrm{h}(n=18)$ & $14(77.8)$ \\
Procalcitonin $>0.5 \mathrm{ng} / \mathrm{ml}, n / \mathrm{N}(\%)(\mathrm{N}=24)$ & $8(33.3)$ \\
\hline
\end{tabular}

${ }^{\mathrm{a}} \mathrm{PaCO}_{2}$, partial pressure of arterial carbon dioxide; WBC, white blood cell. Data were represented as number (percentage). 
Significantly higher levels of serum cytokines in patients with H7N9 avian influenza

SIRS is a consequence of cytokine storm, so we evaluated the levels of serum cytokines by CBA in HCs and in the patients with H7N9 influenza at the time of admission. We detected IL-2, IL-6, IL-8 and IL-10, but we did not detect IFN- $\gamma$, TNF- $\alpha$, TNF- $\beta$, IL- $1 \beta$, IL-4, IL-5 or IL-12p70. We found that the levels of serum IL-6 $(P=0.0098)$, IL-8 $(P=0.0010)$ and IL-10 $(P=0.015)$ in the patients were significantly higher than those in the HCs (Figure 1). However, there was no significant difference in the levels of serum IL-2 between these two groups $(P=0.19)$.

\section{Alteration in number of peripheral blood immunocompetent cells in patients with H7N9 avian influenza}

Next, we examined the numbers of peripheral blood immunocompetent cells. We found that $66.7 \%$ of patients developed lymphocytopenia (lymphocytes $<0.8 \times 10^{9} / \mathrm{L}$ ) and $40.7 \%$ had abnormally low monocyte counts (monocytes $\left.<0.12 \times 10^{9} / \mathrm{L}\right)$. However, only $25.9 \%$ of patients had neutropenia (neutrophils $<2.0 \times 10^{9} / \mathrm{L}$ ). Further flow cytometric analysis indicated that the percentages of CD3+ T cells $(58.88 \pm 16.34 \%$ vs. $67.22 \pm 9.22 \% ; P=0.020)$ and
CD8+ T cells $(20.18 \pm 8.58 \%$ vs. $24.19 \pm 6.06 \% ; P=0.045)$ were significantly lower in the patients than in the HCs. In addition, we found no significant differences in the frequency of peripheral blood CD $3+\mathrm{CD} 4+\mathrm{T}$ cells and CD3 - CD56+ NK cells between the patients and the $\mathrm{HCs}(37.46 \pm 13.50 \%$ vs. $38.61 \pm 8.84 \%$; $\mathrm{P}=0.70$ for $\mathrm{CD} 4+$ T cells; and $15.10 \pm 11.00 \%$ vs. $19.73 \pm 9.55 \% ; P=0.095$ for NK cells) (Table 3 ).

CD38 is a marker of T-cell activation, and Tim-3 is a surface marker of T-cell exhaustion [13]. Further characterization of functional $\mathrm{T}$ cells revealed that the percentages of peripheral blood CD $38+$ CD $4+$ and CD38 + CD $8+$ $\mathrm{T}$ cells in the patients were significantly higher than those in the $\operatorname{HCs}(P=0.0068$ and $P<0.001$, respectively) (Figure 2). Concomitantly, the percentages of peripheral blood Tim-3 + CD4+ and Tim-3 + CD $8+\mathrm{T}$ cells in the patients were significantly higher than those in the HCs $(P<0.001$ for both).

We next assessed the functional phenotypes of peripheral blood monocytes and found that the percentages of HLA-DR + CD14+ and Tim-3 + CD14+ monocytes in total CD14+ cells in patients were significantly lower than those in the HCs $(P=0.043$ and $P=0.0029$, respectively) (Figure 3). Collectively, these data suggest that patients with H7N9 avian influenza had immunodysfunction.
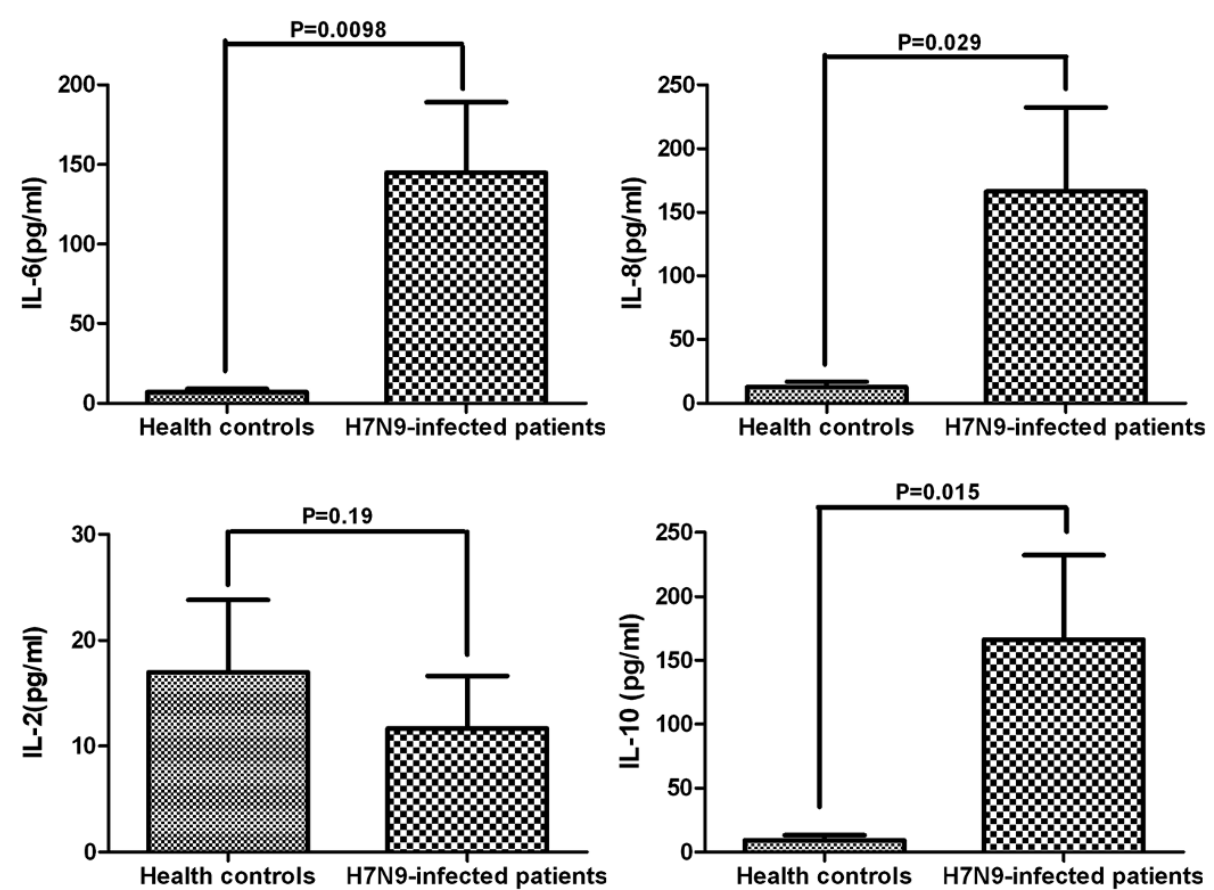

Figure 1 Levels of circulating cytokines in patients with H7N9 avian influenza. Serum samples were prepared from 10 patients and 10 healthy controls. We carried out cytometric bead arrays to measure the concentrations of serum interleukin $1 \beta$ (IL-1 $\beta), I L-2, I L-4, I L-5, I L-6, I L-8, I L-10, I L-12 p 70$, tumor necrosis factor a (TNF-a), TNF- $\beta$ and interferon $\gamma$ (IFN- $\gamma$ ) in individual samples. Data shown are the mean values of individual cytokines in each participant from two separate experiments, which we analyzed by Mann-Whitney $U$ test. Under our experimental conditions, we found no detectable levels of serum IL-1 $\beta$, IL-4, IL-5, IL-12p70, TNF-a, TNF- $\beta$ or IFN- $\gamma$ in these participants (data not shown). Error bars were shown in each column. 
Table 3 Comparison of counts and percentages of lymphocytes and lymphocyte subsets between patients with H7N9 virus infection and healthy controls ${ }^{a}$

\begin{tabular}{llll}
\hline Variables & Patients $(\boldsymbol{n = 2 7 )}$ & Healthy controls $(\boldsymbol{n}=\mathbf{3 0})$ & $\boldsymbol{P}$-value \\
\hline Neutrophils $<2.0 \times 10^{9} / \mathrm{L}, n(\%)$ & $7(25.9)$ & None & - \\
Monocytes $<0.12 \times 10^{9} / \mathrm{L}, n(\%)$ & $10(40.7)$ & None & - \\
Lymphocytes $<0.8 \times 10^{9} / \mathrm{L}, n(\%)$ & $18(66.7)$ & None & - \\
CD3+ T cells (\%) & $58.88 \pm 16.34$ & $67.22 \pm 9.22$ & 0.020 \\
CD4+ T cells (\%) & $37.46 \pm 13.50$ & $38.61 \pm 8.84$ & 0.70 \\
CD8+ T cells (\%) & $20.18 \pm 8.58$ & $24.19 \pm 6.06$ & 0.045 \\
Natural killer cells (\%) & $15.10 \pm 11.00$ & $19.73 \pm 9.55$ & 0.095 \\
\hline
\end{tabular}

${ }^{\text {a }}$ Statistical analysis was performed by Student's $t$-test.

Continuous data were expressed as mean \pm SD and categorical data were represented as number (percentage).

\section{Discussion}

In the present study, we examined the immune system alterations in patients with H7N9 avian influenza. We found that a high percentage of patients developed SIRS accompanied by a high percentage of activated $\mathrm{T}$ cells and increased levels of serum cytokines. Concomitantly, many patients displayed lymphocytopenia, abnormally low monocyte counts, T-cell exhaustion and monocyte dysfunction, which are characteristic of immune paralysis.

The presence of SIRS is predictive of organ dysfunction and mortality $[14,15]$. We found that $70 \%$ of patients had at least two concurrent SIRS components and detected significantly higher levels of serum IL-6 and IL- 8 in the patients than in HCs, which may explain the high morbidity and mortality associated with this disease. However, we did not detect significant alterations in the levels of serum IFN- $\gamma$ or TNF- $\alpha$ in these patients. This cytokine profile is analogous to that of patients with severe acute respiratory syndrome (SARS) [16,17]. Furthermore, it has been reported that patients with either H7N9 virus influenza or SARS coronavirus-related illness shared striking similarities with regard to their clinical presentation and disease progression. Therefore, it is possible that the pathogenesis of H7N9 virus infection is similar to that of SARS coronavirusrelated infection [18]. Although patients with severe influenza induced by the $\mathrm{H} 1 \mathrm{~N} 1$ and $\mathrm{H} 5 \mathrm{~N} 1$ viruses develop a "cytokine storm," including high levels of serum IFN- $\gamma$ and TNF- $\alpha$, which are commonly associated with rapid progression and poor prognosis $[11,19,20]$, we did not detect abnormal levels of serum IFN- $\gamma$ or TNF- $\alpha$ in patients with H7N9 virus infection. These findings suggest that different immune responses may occur in patients with varying types of influenza virus infection. The investigators in one recent study reported that a high frequency of programmed death receptor 1 (PD-1), and its ligand 1 (PD-L1), that expressed T cells impaired T-cell responses to H1N1 infection in patients with influenza [21]. It is possible that similar mechanisms may underlie the failure to detect abnormal levels of serum IFN$\gamma$ and TNF- $\alpha$ in patients with H7N9 virus infection. Although proinflammatory IFN- $\gamma$ and TNF- $\alpha$ responses usually occur at early stages of immune responses, it is also possible that the failure to detect abnormal levels of serum IFN- $\gamma$ or TNF- $\alpha$ may stem from missing the very early time point in our study. Therefore, further studies are needed to clarify the mechanisms underlying the pathogenesis of H7N9 virus infection and host immune responses.

Our results show that many patients with severe avian H7N9 influenza developed T-cell lymphocytopenia. Such a phenomenon is commonly reported in patients with SARS. However, pneumonia caused by other common respiratory viruses are usually associated with a normal or elevated lymphocyte count [22]. The lymphocytopenia in patients with H7N9 avian influenza may be a key factor leading to high morbidity and mortality, because lymphocytopenia is an independent risk factor for ARDS, which is a very dangerous condition for patients with secondary infections [1]. The lymphocytopenia in these patients likely derives from the migration of $\mathrm{T}$ lymphocytes into the target tissues, such as the lungs. Alternatively, the lymphocytopenia may stem from virus-stimulated, activation-induced T-cell apoptosis and virus infection-related bone marrow suppression [23].

$\mathrm{T}$ lymphocytes play a pivotal role in the defense of viral infection by directly killing virus-infected cells. In this study, we found significantly higher frequencies of CD38+CD4+, CD38 + CD8+, Tim-3 + CD4+ and Tim$3+\mathrm{CD} 8+\mathrm{T}$ cells in patients with H7N9 avian influenza compared with those in the HCs. It is well-known that CD38 and Tim-3 expression are associated with T-cell activation [13]. The higher frequency of CD38+ and Tim-3+ T cells in patients with H7N9 avian influenza indicated that viral infection induced significant $\mathrm{T}$-cell activation. However, Tim-3 on activated T cells usually provides a negative signal for effector $\mathrm{T}$-cell function and leads to T-cell functional exhaustion [13,24,25]. Furthermore, engagement of Tim-3 by its specific ligand of galectin-9 can trigger T-cell apoptosis [26]. Notably, IFN$\gamma$ is a potent inducer of galectin-9 protein expression, thus the low IFN- $\gamma$ expression in patients with severe H7N9 influenza may limit the production of galectin-9, leading to a high frequency of impotent Tim-3+ T cells. Thus, in 


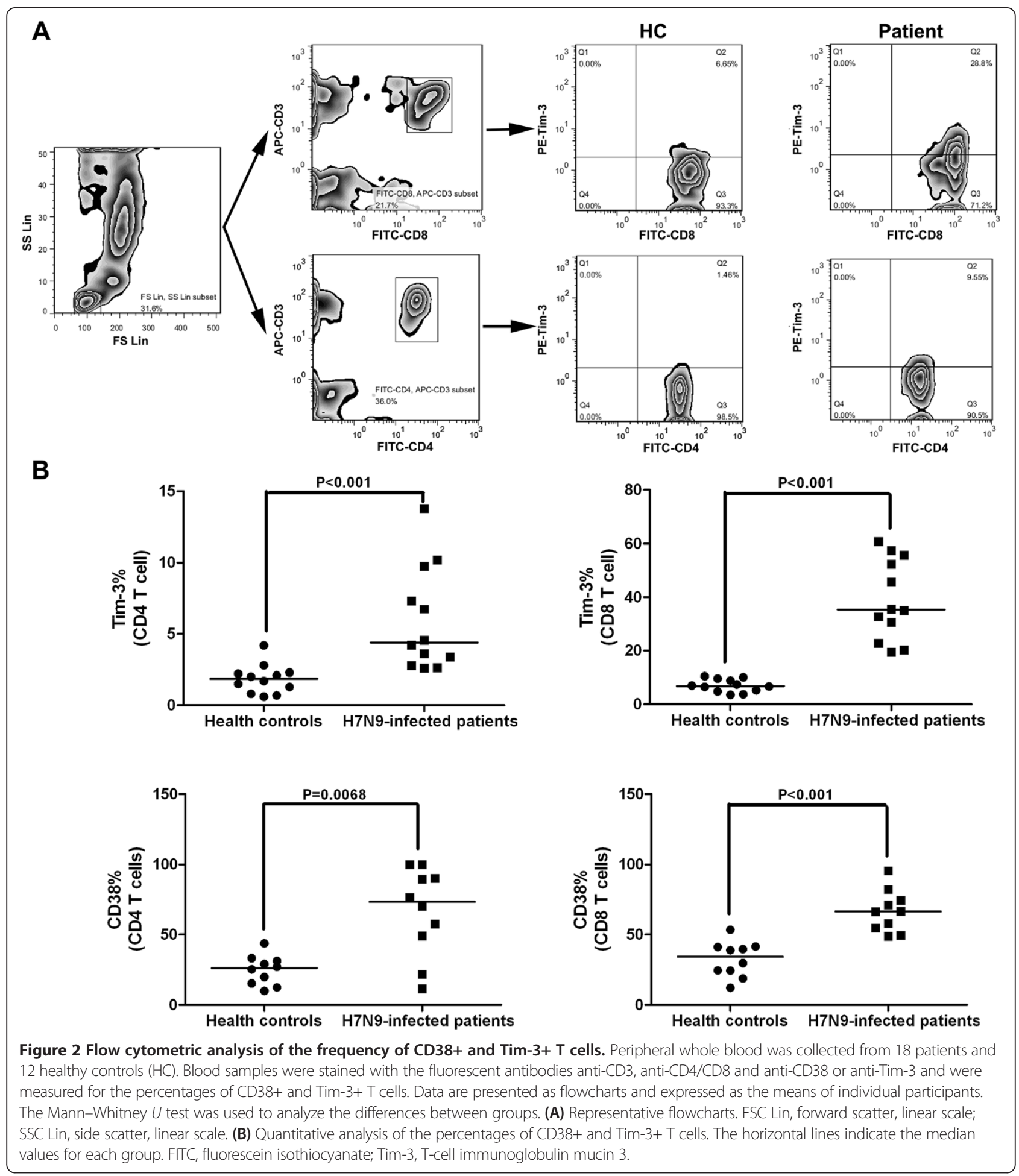

turn, aberration of T-cell activation in patients with H7N9 avian influenza may render T-cell exhaustion and apoptosis or impotence, leading to poor immune responses. We are interested in further investigating the levels of galectin-9 and T-cell function to discern the precise mechanisms underlying immune responses to $\mathrm{H} 7 \mathrm{~N} 9$ virus infection in humans.

Monocytes are an important component of the innate immune system, which recognizes pathogens, secretes proinflammatory cytokines and chemokines to initiate 


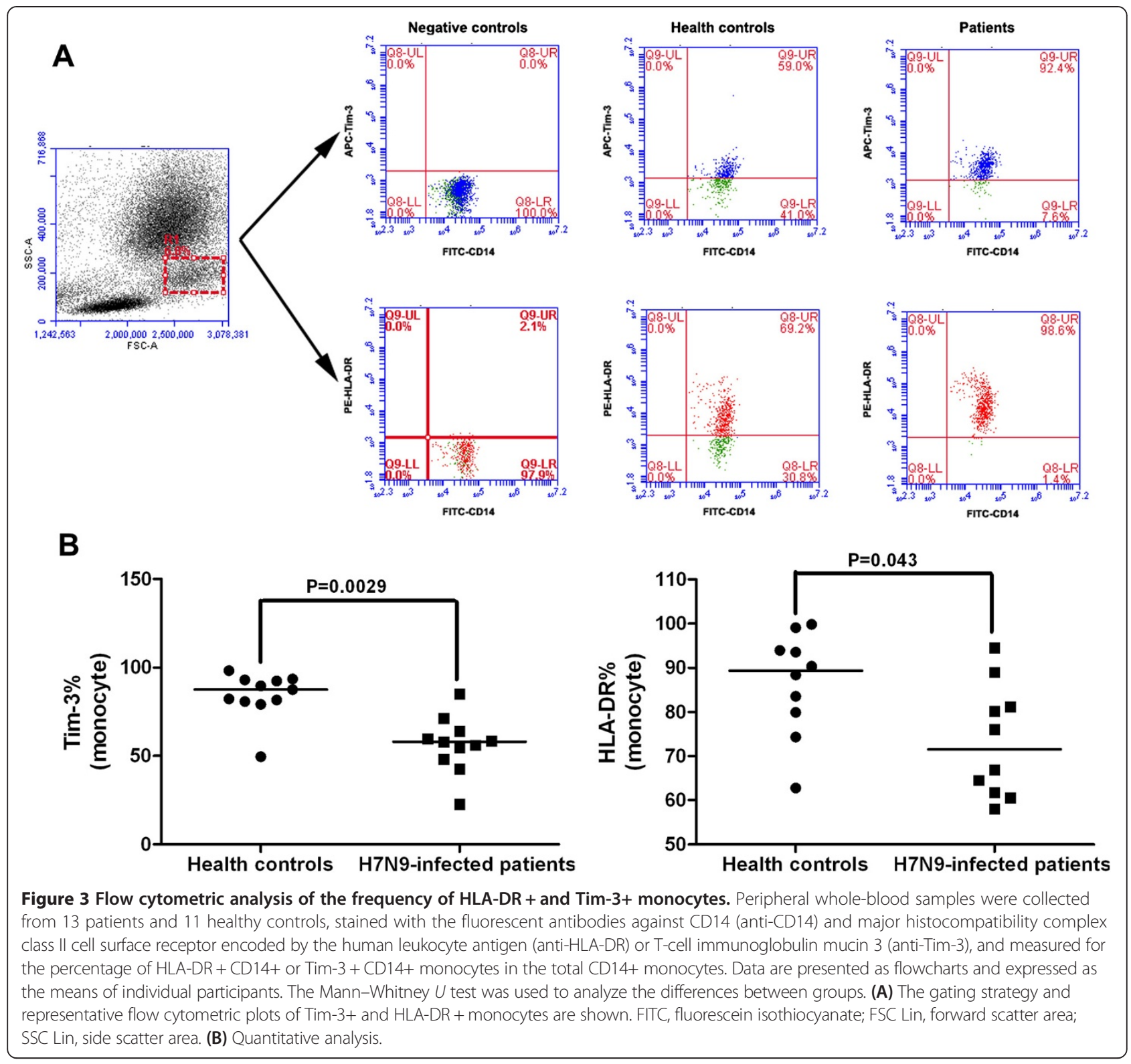

the immune response, and presents antigens to trigger adaptive immune responses [27]. In this study, we found a significantly reduced frequency of peripheral blood HLA-DR + CD14+ and Tim-3 + CD14+ monocytes in patients with H7N9 avian influenza, at levels similar to those in patients with septic shock [28], trauma [29] and acute liver failure [30], as well as postoperative patients [31]. In these clinical settings, downregulation of HLA-DR expression usually represents the functional impairment of monocytes and is associated with adverse outcomes. In addition, the reduced levels of Tim-3 expression on monocytes may contribute to the functional deactivation of monocytes, as it was reported previously that constitutive Tim-3 expression in naïve and resting immunocompetent cells promotes inflammation [32].
In addition, we noted that nearly one-half of the patients in our study had evidence of secondary infection, which is very dangerous because secondary bacterial or fungal infection is a common factor leading to mortality in patients with H7N9 avian influenza [1]. We speculate that the increased predisposition to secondary infection of patients is related to the deranged immune response. Therefore, it is crucial for clinicians to pay special attention to patients with severe influenza by modulating immunocompetent cell function to limit adverse consequences in the clinic.

We recognize that our study has limitations, including its small sample size, measurement at one time point for a few markers of functional immunocompetent cells and the lack of antigen-specific T-cell immunity. Therefore, 
further studies are warranted to measure longitudinally the dynamic changes in the immunological status of patients during the whole time course of H7N9 infection and to assess the function of different types of immunocompetent cells using other functional markers (for example, CD25, CD69, PD-1 and LAG-3) and antigenspecific T-cell immunity by ex vivo experiments in a larger sample population. We are interested in further investigating the molecular mechanisms underlying the immunoderangement in patients with H7N9 avian influenza.

\section{Conclusions}

Overall, our findings reveal that patients with H7N9 avian influenza commonly develop SIRS accompanied by T-cell lymphocytopenia and exhaustion, as well as monocyte dysfunction. The immunoderangement may be associated with the high mortality rate associated with this disease.

\section{Key messages}

- Patients with H7N9 avian influenza usually develop ARDS and secondary infection and have a high mortality rate.

- A hyperactivated inflammatory response and an anti-inflammatory response occur concomitantly in patients with H7N9 avian influenza.

- Such immune derangement may contribute to the rapid progression of and high mortality associated with this disease.

\begin{abstract}
Abbreviations
ARDS: Acute respiratory distress syndrome; CBA: Cytometric bead array; CRP: C-reactive protein; ECMO: Extracorporeal membrane oxygenation; ESR: Erythrocyte sedimentation rate; H7N9: Avian influenza A; HBV: Hepatitis B virus; HCV: Hepatitis C virus; SARS: Severe acute respiratory syndrome; SIRS: Systemic inflammatory response syndrome.
\end{abstract}

\section{Competing interests}

The authors declare that they have no competing interests.

\begin{abstract}
Authors' contributions
WW carried out the RT-PCR and flow cytometric analysis, participated in the design of the study and helped to draft the manuscript. YS carried out the cytokine measurements, participated in the design of the study and helped to draft the manuscript. HG analyzed and interpreted the results and revised the manuscript. WL and JS participated in the design of the study and revised the manuscript. LL conceived of the study, participated in its design and coordination and helped to draft the manuscript. All authors read and approved the final manuscript.
\end{abstract}

\footnotetext{
Acknowledgements

The manuscript was proofread by Medjaden Bioscience Limited. This work was supported by the 12th Five-Year Significant New Drugs Creation Plan of the Ministry of Science and Technology of China (2011ZX09302-003-03), the Technology Group Project for Infectious Disease Control of Zhejiang Province (2009R50041) and the Chinese National Natural Science Foundation (81200301), as well as by a grant from the Health Department of Zhejiang Province (2012KYA087).
}

Received: 18 November 2013 Accepted: 20 February 2014 Published: 24 Mar 2014

\section{References}

1. Gao HN, Lu HZ, Cao B, Du B, Shang H, Gan JH, Lu SH, Yang YD, Fang Q, Shen YZ, Xi XM, Gu Q, Zhou XM, Qu HP, Yan Z, Li FM, Zhao W, Gao ZC, Wang GF, Ruan LX, Wang WH, Ye J, Cao HF, Li XW, Zhang WH, Fang XC, He J, Liang WF, Xie J, Zeng $M$, et al: Clinical findings in 111 cases of influenza A (H7N9) virus infection. N Engl J Med 2013, 368:2277-2285. A published erratum appears in N Engl J Med 2013, 369:1869.

2. Uyeki TM, Cox NJ: Global concerns regarding novel influenza A (H7N9) virus infections. N Engl J Med 2013, 368:1862-1864.

3. Li Q, Zhou L, Zhou M, Chen Z, Li F, Wu H, Xiang N, Chen E, Tang F, Wang D, Meng L, Hong Z, Tu W, Cao Y, Li L, Ding F, Liu B, Wang M, Xie R, Gao R, Li X, Bai T, Zou S, He J, Hu J, Xu Y, Chai C, Wang S, Gao Y, Jin L, et al: Epidemiology of human infections with avian influenza $A(H 7 N 9)$ virus in China. N Engl J Med 2014, 370:520-532.

4. Gao R, Cao B, Hu Y, Feng Z, Wang D, Hu W, Chen J, Jie Z, Qiu H, Xu K, Xu X, Lu H, Zhu W, Gao Z, Xiang N, Shen Y, He Z, Gu Y, Zhang Z, Yang Y, Zhao X, Zhou L, Li X, Zou S, Zhang Y, Li X, Yang L, Guo J, Dong J, Li Q, et al: Human infection with a novel avian-origin influenza $A$ (H7N9) virus. N Engl J Med 2013, 368:1888-1897.

5. Zhang W, Wang L, Hu W, Ding F, Sun H, Li S, Huang L, Li C: Epidemiologic characteristics of cases for influenza $A(H 7 N 9)$ virus infections in China. Clin Infect Dis 2013, 57:619-620.

6. Zhu H, Wang D, Kelvin DJ, Li L, Zheng Z, Yoon SW, Wong SS, Farooqui A, Wang J, Banner D, Chen R, Zheng R, Zhou J, Zhang Y, Hong W, Dong W, Cai Q, Roehrl MH, Huang SS, Kelvin AA, Yao T, Zhou B, Chen X, Leung GM, Poon LL, Webster RG, Webby RJ, Peiris JS, Guan Y, Shu Y: Infectivity, transmission, and pathology of human-isolated H7N9 influenza virus in ferrets and pigs. Science 2013, 341:183-186. A published erratum appears in Science 2013, 341:959.

7. Tharakaraman K, Jayaraman A, Raman R, Viswanathan K, Stebbins NW, Johnson D, Shriver Z, Sasisekharan V, Sasisekharan R: Glycan receptor binding of the influenza A virus H7N9 hemagglutinin. Cell 2013, 153:1486-1493.

8. Chen Y, Liang W, Yang S, Wu N, Gao H, Sheng J, Yao H, Wo J, Fang Q, Cui D, Li Y, Yao X, Zhang Y, Wu H, Zheng S, Diao H, Xia S, Zhang Y, Chan KH, Tsoi HW, Teng JL, Song W, Wang P, Lau SY, Zheng M, Chan JF, To KK, Chen H, Li L, Yuen KY: Human infections with the emerging avian influenza A H7N9 virus from wet market poultry: clinical analysis and characterisation of viral genome. Lancet 2013, 381:1916-1925.

9. Hu Y, Lu S, Song Z, Wang W, Hao P, Li J, Zhang X, Yen HL, Shi B, Li T, Guan W, Xu L, Liu Y, Wang S, Zhang X, Tian D, Zhu Z, He J, Huang K, Chen H, Zheng L, Li X, Ping J, Kang B, Xi X, Zha L, Li Y, Zhang Z, Peiris M, Yuan Z: Association between adverse clinical outcome in human disease caused by novel influenza A H7N9 virus and sustained viral shedding and emergence of antiviral resistance. Lancet 2013, 381:2273-2279.

10. Bernard GR, Artigas A, Brigham KL, Carlet J, Falke K, Hudson L, Lamy M, Legall JR, Morris A, Spragg R: The American-European Consensus Conference on ARDS. Definitions, mechanisms, relevant outcomes, and clinical trial coordination. Am J Respir Crit Care Med 1994, 149:818-824.

11. de Jong MD, Simmons CP, Thanh TT, Hien VM, Smith GJD, Chau TNB, Hoang DM, Chau NW, Khanh TH, Dong VC, Qui PT, Cam BV, Ha DQ, Guan Y, Peiris JSM, Chinh NT, Hien TT, Farrar J: Fatal outcome of human influenza A (H5N1) is associated with high viral load and hypercytokinemia. Nat Med 2006, 12:1203-1207.

12. American College of Chest Physicians/Society of Critical Care Medicine Consensus Conference: Definitions for sepsis and organ failure and guidelines for the use of innovative therapies in sepsis. Crit Care Med 1992, 20:864-874.

13. Jones RB, Ndhlovu LC, Barbour JD, Sheth PM, Jha AR, Long BR, Wong JC, Satkunarajah M, Schweneker M, Chapman JM, Gyenes G, Vali B, Hyrcza MD Yue FY, Kovacs C, Sassi A, Loutfy M, Halpenny R, Persad D, Spotts G, Hecht FM, Chun TW, McCune JM, Kaul R, Rini JM, Nixon DF, Ostrowski MA: Tim-3 expression defines a novel population of dysfunctional $\mathrm{T}$ cells with highly elevated frequencies in progressive HIV-1 infection. J Exp Med 2008, 205:2763-2779.

14. Talmor M, Hydo L, Barie PS: Relationship of systemic inflammatory response syndrome to organ dysfunction, length of stay, and mortality in critical surgical illness: effect of intensive care unit resuscitation. Arch Surg 1999, 134:81-87.

15. Calandra T, Baumgartner JD, Grau GE, Wu MM, Lambert PH, Schellekens J, Verhoef J, Swiss-Dutch $J 5$ Immunoglobulin Study Group, Glauser MP: 
Prognostic values of tumor necrosis factor/cachectin, interleukin-1, interferon- $a$, and interferon- $\gamma$ in the serum of patients with septic shock. Swiss-Dutch J5 immunoglobulin study group. J Infect Dis 1990, 161:982-987.

16. Jiang Y, Xu J, Zhou C, Wu Z, Zhong S, Liu J, Luo W, Chen T, Qin Q, Deng P: Characterization of cytokine/chemokine profiles of severe acute respiratory syndrome. Am J Respir Crit Care Med 2005, 171:850-857.

17. Tang NL, Chan PK, Wong CK, To KF, Wu AK, Sung YM, Hui DS, Sung JJ, Lam CW: Early enhanced expression of interferon-inducible protein-10 (CXCL-10) and other chemokines predicts adverse outcome in severe acute respiratory syndrome. Clin Chem 2005, 51:2333-2340.

18. Spiegel M, Pichlmair A, Martínez-Sobrido L, Cros J, García-Sastre A, Haller O, Weber $F$ : Inhibition of $\beta$ interferon induction by severe acute respiratory syndrome coronavirus suggests a two-step model for activation of interferon regulatory factor 3. J Virol 2005, 79:2079-2086.

19. Woo PCY, Tung ETK, Chan KH, Lau CCY, Lau SKP, Yuen KY: Cytokine profiles induced by the novel swine-origin influenza A/H1N1 virus: implications for treatment strategies. J Infect Dis 2010, 201:346-353.

20. Almansa R, Anton A, Ramirez P, Martin-Loeches I, Banner D, Pumarola T, Xu L, Blanco J, Ran L, Lopez-Campos G, Martin-Sanchez F, Socias L, Loza A, Andaluz D, Maravi E, Gordón M, Gallegos MC, Fernandez V, León C, Merino P, Marcos MA, Gandía F, Bobillo F, Resino S, Eiros JM, Castro C, Mateo P, Gonzalez-Rivera M, Rello J, de Lejarazu RO, et al: Direct association between pharyngeal viral secretion and host cytokine response in severe pandemic influenza. BMC Infect Dis 2011, 11:232.

21. Valero-Pacheco N, Arriaga-Pizano L, Ferat-Osorio E, Mora-Velandia LM, Pastelin-Palacios R, Villasís-Keever MÁ, Alpuche-Aranda C, Sánchez-Torres LE, Isibasi A, Bonifaz L, López-Macías C: PD-L1 expression induced by the 2009 pandemic influenza $A(H 1 N 1)$ virus impairs the human T cell response. Clin Dev Immunol 2013, 2013:989673.

22. Cui W, Fan Y, Wu W, Zhang F, Wang JY, Ni AP: Expression of lymphocytes and lymphocyte subsets in patients with severe acute respiratory syndrome. Clin Infect Dis 2003, 37:857-859.

23. Chen J, Subbarao K: The immunobiology of SARS. Annu Rev Immunol 2007, 25:443-472.

24. Golden-Mason L, Palmer BE, Kassam N, Townshend-Bulson L, Livingston S, McMahon BJ, Castelblanco N, Kuchroo V, Gretch DR, Rosen HR: Negative immune regulator Tim-3 is overexpressed on T cells in hepatitis $C$ virus infection and its blockade rescues dysfunctional $\mathrm{CD} 4^{+}$and $\mathrm{CD} 8^{+} \mathrm{T}$ cells. J Virol 2009, 83:9122-9130.

25. Wu W, Shi Y, Li S, Zhang Y, Liu Y, Wu Y, Chen Z: Blockade of Tim-3 signaling restores the virus-specific $\mathrm{CD} 8^{+} \mathrm{T}$-cell response in patients with chronic hepatitis B. Eur J Immunol 2012, 42:1180-1191.

26. Lv K, Zhang Y, Zhang M, Zhong M, Suo Q: Galectin-9 ameliorates Con A-induced hepatitis by inducing $\mathrm{CD} 4^{+} \mathrm{CD} 25^{\text {low/int }}$ effector T-cell apoptosis and increasing regulatory T cell number. PLoS One 2012, 7:e48379.

27. Gordon S, Taylor PR: Monocyte and macrophage heterogeneity. Nat Rev Immunol 2005, 5:953-964.

28. Pangault $C$, Le Tulzo $Y$, Tattevin P, Guilloux V, Bescher N, Drénou B: Down-modulation of granulocyte macrophage-colony stimulating factor receptor on monocytes during human septic shock. Crit Care Med 2006, 34:1193-1201.

29. Flohé S, Lendemans S, Selbach C, Waydhas C, Ackermann M, Schade FU, Kreuzfelder $\mathrm{E}$ : Effect of granulocyte-macrophage colony-stimulating factor on the immune response of circulating monocytes after severe trauma. Crit Care Med 2003, 31:2462-2469.

30. Antoniades CG, Berry PA, Davies ET, Hussain M, Bernal W, Vergani D, Wendon J: Reduced monocyte HLA-DR expression: a novel biomarker of disease severity and outcome in acetaminophen-induced acute liver failure. Hepatology 2006, 44:34-43.

31. Tschaikowsky K, Hedwig-Geissing M, Schiele A, Bremer F, Schywalsky M, Schüttler J: Coincidence of pro- and anti-inflammatory responses in the early phase of severe sepsis: longitudinal study of mononuclear histocompatibility leukocyte antigen-DR expression, procalcitonin,
C-reactive protein, and changes in T-cell subsets in septic and postoperative patients. Crit Care Med 2002, 30:1015-1023.

32. Anderson AC, Anderson DE, Bregoli L, Hastings WD, Kassam N, Lei $C$ Chandwaskar R, Karman J, Su EW, Hirashima M, Bruce JN, Kane LP, Kuchroo VK, Hafler DA: Promotion of tissue inflammation by the immune receptor Tim-3 expressed on innate immune cells. Science 2007, 318:1141-1143.

\section{$10.1186 / \operatorname{cc} 13788$}

Cite this article as: Wu et al: Immune derangement occurs in patients with H7N9 avian influenza. Critical Care 2014, 18:R43

\section{Submit your next manuscript to BioMed Central and take full advantage of:}

- Convenient online submission

- Thorough peer review

- No space constraints or color figure charges

- Immediate publication on acceptance

- Inclusion in PubMed, CAS, Scopus and Google Scholar

- Research which is freely available for redistribution

Submit your manuscript at www.biomedcentral.com/submit
C Biomed Central 